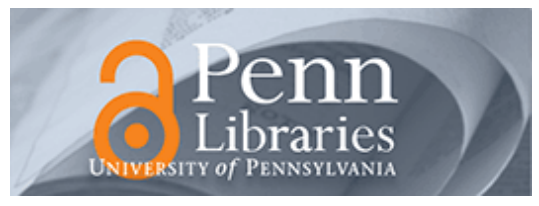

University of Pennsylvania

ScholarlyCommons

Management Papers

Wharton Faculty Research

$12-2007$

\title{
McDonald's - Much Maligned, but an Engine of Economic Development
}

Adrian E. Tschoegl

University of Pennsylvania

Follow this and additional works at: https://repository.upenn.edu/mgmt_papers

Part of the Business Administration, Management, and Operations Commons, and the Training and Development Commons

Recommended Citation

Tschoegl, A. E. (2007). McDonald's -- Much Maligned, but an Engine of Economic Development. Global Economy Journal, 7(4), http://dx.doi.org/10.2202/1524-5861.1327

This paper is posted at ScholarlyCommons. https://repository.upenn.edu/mgmt_papers/165

For more information, please contact repository@pobox.upenn.edu. 


\title{
McDonald's -- Much Maligned, but an Engine of Economic Development
}

\author{
Abstract \\ and as a symbol of the United States. However, examining McDonald's internationalization and \\ development abroad suggests that McDonald's and the others of its ilk are sources of development for \\ mid-range countries. McDonald's brings training in management, encourages entrepreneurship directly \\ local suppliers, fosters exports by their suppliers, and has positive external effects on productivity and \\ standards of service, cleanliness, and quality in the host economies. \\ Keywords \\ fast-food, McDonald's, productivity spillovers, foreign direct investment \\ Disciplines \\ Business Administration, Management, and Operations | Training and Development
}

Critics have excoriated the US fast-food industry in general, and McDonald's most particularly, both per se through franchises and indirectly through demonstration effects, creates backward linkages that develop 


\title{
Global Economy Journal
}

Volume 7, Issue 4

2007

Article 5

\section{McDonald's - Much Maligned, But an Engine of Economic Development}

\author{
Adrian E. Tschoegl*
}

*Wharton School of the University of Pennsylvania, tschoegl@alum.mit.edu 


\title{
McDonald's - Much Maligned, But an Engine of Economic Development*
}

\author{
Adrian E. Tschoegl
}

\begin{abstract}
Critics have excoriated the US fast-food industry in general, and McDonald's most particularly, both per se and as a symbol of the United States. However, examining McDonald's internationalization and development abroad suggests that McDonald's and the others of its ilk are sources of development for mid-range countries. McDonald's brings training in management, encourages entrepreneurship directly through franchises and indirectly through demonstration effects, creates backward linkages that develop local suppliers, fosters exports by their suppliers, and has positive external effects on productivity and standards of service, cleanliness, and quality in the host economies.
\end{abstract}

KEYWORDS: fast-food, McDonald's, productivity spillovers, foreign direct investment

\footnotetext{
*The author came to the US in 1960 and ate his first McDonald's hamburger in Madison, Wisconsin, in 1961, at a time when the signs said, "Over 125 million served." He has happily eaten at McDonald's several times a year ever since, but unfortunately never bought its shares. He has not consulted for McDonald's or any other fast food company, and does not expect to in the future, though he would not be averse to doing so, having recently renovated the kitchen in his house. The author would also like to thank participants at seminars at Victoria University of Wellington and the University of Melbourne for their comments and criticisms of an earlier draft. (What motivated the disclaimer above was the response of a participant at one of these seminars, whose questions implied that only venality could explain the author's suggesting that McDonald's might not represent unalloyed evil, the participant having presumably ruled out an alternative hypothesis of stupidity.) This paper draws in part on information gathered for the case study, "The sun never sets on the Golden Arches": McDonald's internationalizes' that the author and his colleague Mauro Guillén prepared for classroom use at the Wharton School of the University of Pennsylvania. Lastly, the author would like to thank the anonymous referee for encouraging him to write more forcefully.
} 
Tschoegl: McDonald's -- Engine of Development

\subsection{Introduction}

"Mal bouffe"; junk food; seducer of children; employer of burger-flippers; exploiter of low-skilled labor; symbol of cultural imperialism; symbol of corporate greed; symbol of America. McDonald's is a target of criticism aimed at its products and itself (Schlosser 2002), and even suffers collateral damage from criticism targeted at its country of origin (Faulk and Usunier 2004). For those interested in the company's reaction, Greenberg and Naim (2001) is the report of an interview in which Naim lays out the common charges to which Greenberg, the then CEO of McDonald's, responds. Despite the charges, Interbrands estimated that in 2006, McDonald's was the eighth most valuable brand name in the world, with a market value of US\$29.4bn.

What is interesting about the accusations of illegitimacy (unlike claims of liability in accidents or situations of product liability) is that the accusations typically involve a diffuse set of victims, victims who are indirect in that they are neither the accusers themselves nor even frequently direct consumers. ${ }^{1}$ The accusations are difficult clearly to prove or disprove, and reside in the ethical or moral domain rather than in the legal domain. Kostova and Zaheer (1999) have a conceptual paper that extends the discussion of organizational legitimacy to the multinational company.

This paper does not seek to make a balanced assessment of the charges and counter-arguments to them; instead, the paper simply argues that the presence in a country of fast-food chains in general, and McDonald's in particular, is also a source of benefits. The effect of McDonald's entry has been to introduce some positive changes in its host countries and one may therefore consider McDonald's an agent of economic development. More specifically, McDonald's provides management training, encourages entrepreneurship, creates backward linkages that develop the capabilities of suppliers, promotes exports, and generates positive externalities in the form of productivity levels and service standards in the countries in which it operates.

The existing literature on productivity spillovers from FDI (e.g. Kokko 1994 and Kokko et al., 1996) has focused on the manufacturing sector and highlighted issues concerning technology such as gaps, host-country absorptive capacity, and the like as sources of impediments to productivity spillovers. A recent review of the literature (Meyer and Sinani 2006) points out the indeterminacy in results from attempts to estimate spill-over effects. What is interesting about the fast-food industry is that is in the service sector, and that the level of technological sophistication in the production process is not high. (Supply-chain management may be another issue.) Thus the fast-food industry is one in which one might reasonably expect productivity spillovers.

${ }^{1}$ I owe this paragraph in its entirety to Srilata Zaheer. 
The approach of the paper is consistent with the veterinary pathologist W.I.B. Beveridge's $(1961 ; 140)$ argument that:

"More discoveries have arisen from intense observation of very limited material than from statistics applied to large groups. The value of the latter arises mainly in testing hypotheses derived from the former."

That is, the paper examines the specific case of McDonald's internationalization to advance a more nuanced view that the much maligned fast food industry, of which McDonald's in particular is a symbol, is also a source of benefits to its host countries.

\subsection{Some background}

Maurice and Richard McDonald opened their first store in 1940 and their experiences led them to develop and introduce their innovative Speedee Service System in 1948 in San Bernardino, California. ${ }^{2}$ Six years later, Ray Kroc, a salesman of milkshake mixers, discovered their operation. ${ }^{3}$ Impressed, he convinced the brothers to give him a franchise for the Mid-West. Kroc opened his first store in 1955 in Des Plaines, Illinois, and when he bought the brothers out in 1961 for US\$2.7mn, the chain had 100 stores. By the end of 2006, it had 31,667 stores and consolidated revenues of US\$21.6bn.

McDonald's first opened stores outside the United States in 1967 in British Columbia and Puerto Rico; at the time it had not yet entered all 50 states. $^{5}$ In 1970 McDonald's both opened a store in Alaska, completing its presence in all 50 states, and one in Costa Rica, its first outside North America.

When McDonald's first went abroad it was often unique to its host country. First, its US competitors either had not yet gone abroad, or were no further along in their internationalization. Second, not only was fast food itself generally a new concept, but in many countries eating meals outside the home

${ }^{2}$ For a thorough treatment of much of the history, see Love (1990).

${ }^{3}$ Reputedly, other visitors included James McLamore, who went on to found McDonald's rival, Burger King, in Miami in 1957, and Glen Bell, who would found the Taco Bell chain in California in 1962.

${ }^{5}$ Burger King opened a store in Puerto Rico in 1963, beating McDonald's by some four years. Burger King followed McDonald's to Canada in 1969. One can speculate that this sequencing reflected that fact that McDonald's headquarters was in Chicago, while Burger King's was in Miami. 
was uncommon. The uniqueness meant McDonald's had to overcome a liability of foreignness, as well as a liability of newness. Not surprisingly, McDonald's initially faltered and made mistakes, but it learned from them and expanded.

The number of countries in which McDonald's operates (including the US), has followed a classic diffusion-type S-curve (Figure 1). ${ }^{6}$ The number of countries has been essentially flat for several years, but the growth in the number of stores has continued, with the result that at the end of 2006, McDonald's had 17,272 (56\%) of its stores outside the US versus 13,774 (44\%) inside the US.

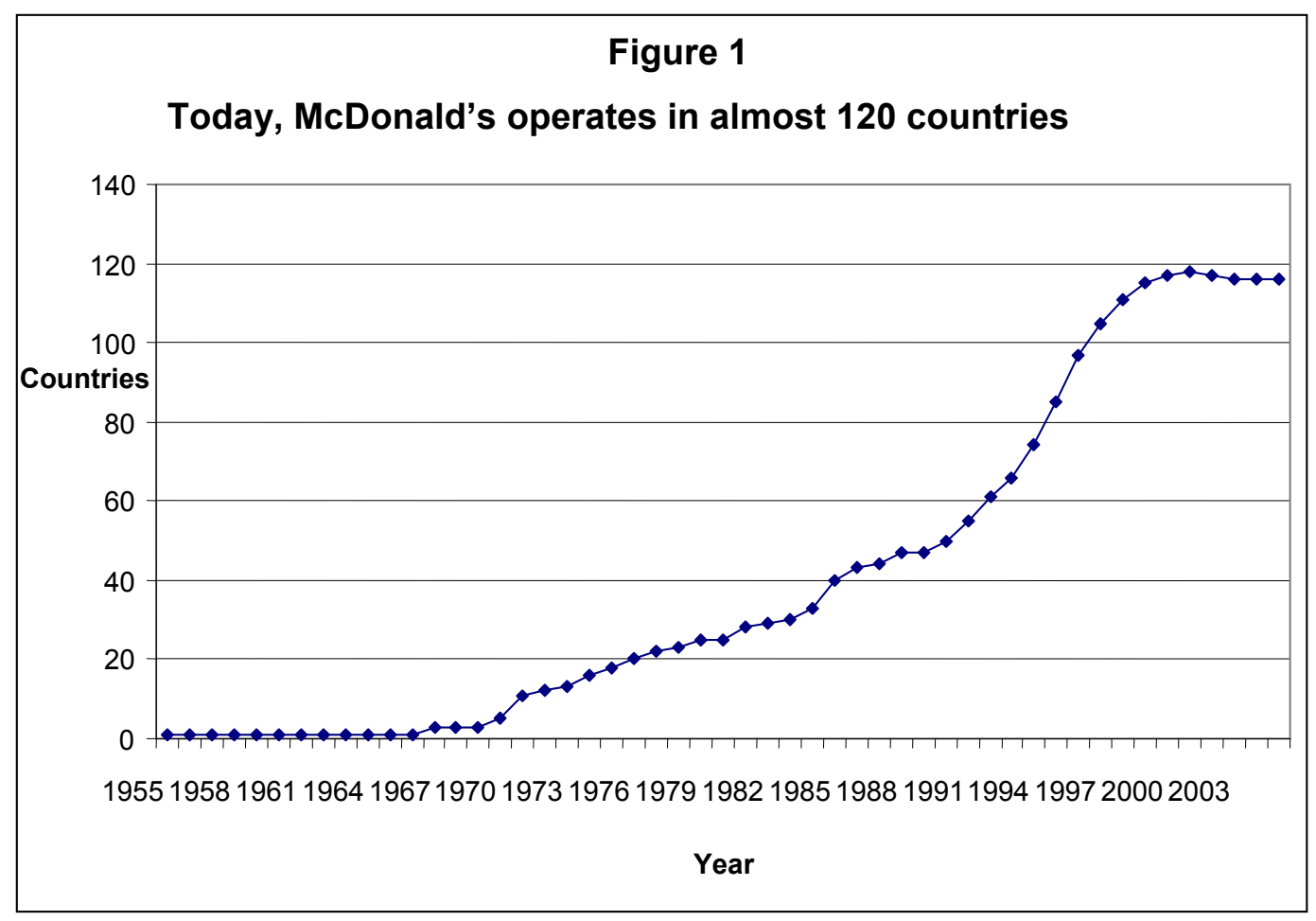

Because McDonald's core competence was a unique process, it generally preferred a greenfield strategy over acquisitions. (There are some partial exceptions. When McDonald's entered Italy in 1985, it grew slowly until in 1996 it acquired Burghy, a local fast-food chain with 80 stores. That acquisition, plus subsequent expansion, boosted the Italian operation to over 320 stores. In New Zealand, McDonald's acquired most of the premises of the failed Georgie's Pies chain.) On one or two other occasions, although McDonald's contemplated

\footnotetext{
${ }^{6}$ The numbers do not fully agree with those McDonald's publishes. McDonald's counts England, Wales, Scotland, and Northern Ireland separately; this Figure simply treats the first entry, into England, as entry into the United Kingdom.
} 
acquisitions, it either could not find appropriate targets, or when it did, the targets would not sell.

As Nachum et al. (2001) point out, for a foreign direct investor to survive in a host country against local competition, it must either do something differently than its competitors, or the same thing but better. What McDonald's and its American competitors brought was in part specific products such as hamburgers (McDonald's, Burger King, and Wendy's), fried chicken (KFC), donuts (Dunkin Donuts and Mister Donut), mocha frapuccinos (Starbucks), American pizza (Dominos and Shakey's), submarine sandwiches (Subway), and the like. But more importantly, what they have diffused is the managerial technology of producing fast food.

There is a time dimension to this internationalization process. Initially the US firms did something different; those that continue to survive do the same thing as their domestic competitors, but they do it better. As Steven Den Beste (2002) once observed:

"That's the critical transition from non-zero-sum to zero-sum. Once the market saturates, you can only grow at the expense of a competitor.

Which finally leads up to the key insight I had a couple of days ago: during the non-zero-sum expansion stage, it is the virtues of each competitor which decide how well they prosper. But after the switch to zero-sum competition, it is their faults which decide who will die."

The model here is one of a transition from a suction economic environment to a pressure economic environment (Kornai 1976). When the US fast-food chains first entered many countries the chains survived because they were bringing something new. Initially, outside North America, McDonald's was ethnic food - a chance to experience something foreign - consistent with the view that globalization increases variety within countries, while reducing it across countries.

Over time, the US chains' customers assimilated the chains in the sense that the customers came to include many people who had grown up eating the chains' food and no longer thought of them as foreign. (Brailsford (2003) has an account of this process in New Zealand.) Furthermore, in many countries local competitors emerged that either adapted the fast-food format to local specialties, or simply acted as an alternate source of hamburgers and the like; now, the chains have to survive based on being at least as efficient as their competitors. Although our focus is on a service company, the underlying logic of the evolution is Vernon's (1966) Product Life Cycle theory. Consistent with that theory, some foreign fast-food companies are now entering the US. 
Tschoegl: McDonald's -- Engine of Development

\subsection{Providing training}

The Speedee Service System required training, leading McDonald's to emphasize this from its earliest days. Furthermore, the QSCV standards (Quality, Service, Cleanliness, and Value), the glue that binds the essentially policentric company's international operations together, depend on training. Trainees learn all 25 positions in a store, from front counter to the grill, on-the-job under the supervision of crew trainers. What matters here for development is not the skills themselves, but the introduction of the staff, many of whom work on a part-time basis and who go on to careers outside McDonald's, to the basic requirements of the workaday world and to a modern organization.

Beaulier and Caplan (2007) cite Sowell (1987, p.36) to the effect that, 'For young workers especially, the things you can learn on ["menial"] jobs responsibility, cooperation, punctuality — can be lifelong assets in many other occupations. Insulating people from such realities is one of the many cruelties perpetuated under the banner of "compassion".'

The parallel is to experience in the military for generations of conscripts around the world. Although such experience is becoming rarer today (outside Israel, the Republic of Korea, Singapore, Switzerland, Taiwan, and some other countries), for millions of men (and in the case of Israel, women too), military service was a formative experience that provided a mental model of organization. The concepts the conscripts and junior officers absorbed included hierarchy, line and staff, manuals and standard operating procedures, attention to detail, neatness and cleanliness standards, and the like. These are also the concepts to which McDonald's exposes its trainees.

As an aside, it is worth noting that employment standards at franchise stores may be better than those at equivalent independent operators on other grounds. Cappelli and Hamori (2007) found for a U.S. sample that once they controlled for industry size and some other issues, franchise operations appeared on important dimensions to offer better jobs with more sophisticated systems of employee management than similar non-franchise operations.

In addition to on site training of staff, McDonald's maintains a system of formal schools. All managers and franchisees receive business management and store operations training in centers or one of McDonald's Hamburger Universities. McDonald's opened its first Hamburger University in 1961 in Oakbrook, Illinois, and the seventh in Hong Kong in 2002. The company also offers mid-management and executive development courses.

McDonald's exercises both selection and development with respect to its franchisees. From among the applicants, McDonald's picks as prospective franchisees individuals who have had significant successful experience with owning or managing multiple business units or multiple departments. It then 
requires the prospective franchisees to undergo training in business operations. The aspirants first work in a McDonald's store for 9-18 months, complete a number of self-directed, part-time (20 hours per week) training modules, participate in seminars, conferences, one-on-one training sessions, and operator training classes, and complete two advanced five-day courses at a Hamburger University. Only then may they become owners. Managers who are not franchisees too undergo a similar combination of on-the-job and formal training. Before it opened in Bolivia, McDonald's required the two local individuals who would be the managing directors of the joint-venture to attend the Oakbrook Hamburger University. Subsequently, the rest of the management team underwent training in McDonald's stores in Uruguay (Anon. 1997).

We know, because McDonald's is proud of the statistic, that over $70 \%$ of its executives started in its stores. What we would like to know, but do not, is how many managers of other companies, especially in developing and emerging economies, received their first management training in McDonald's, or other foreign fast-food chains.

To facilitate the flow of ideas laterally, McDonald's make use of traveling executives (Brandt 1991) and cross-border meetings. In 1991, McDonald's employed five traveling personnel directors who spent as much as 100 days a year abroad. These individuals operated as consultants, keeping local directors informed about what their counterparts in other countries were doing in the personnel area, and helped solve specific, local human resource problems.

McDonald's organizes cross-border meetings by either regions (e.g., a European store managers meeting), or functional areas (e.g., purchasing, construction, or accounting). Now the store managers have started to meet globally. In 2004, Guy Russo, CEO of McDonald's Australia, convened the first ever Global Restaurant Managers convention, to "...create an opportunity for restaurant managers across the globe to come together to share ideas, engage in new experiences and make great friends." Some 3500 store managers from McDonald's stores worldwide converged on Sydney, Australia, to see an exhibition featuring 80 suppliers from all over the world.

\subsection{Promoting entrepreneurship}

McDonald's has promoted the development of entrepreneurship in host economies both directly through its joint-venture and franchise operations, and indirectly in inspiring competition. All this is in addition to any effect it has had on its suppliers (see below).

In Asia, McDonald's has used joint-ventures with local partners with good contacts and local knowledge; local law permitting, McDonald's will take a majority share. In Bolivia McDonald's used a joint-venture, with McDonald's 
and the local partners each providing 50 percent of the US\$6mn necessary to construct the first four stores (Anon. 1997).

In riskier foreign markets, McDonald's simply licenses its name, while retaining an option to acquire. In choosing its licensees McDonald's looks for individuals with good local standing. In Saudi Arabia, the licensee for the Eastern Region is a member of the Saudi royal family; in the Western and Central Region, the licensee is member of one of the richest merchant families in the Kingdom. Because McDonald's favors engaged entrepreneurs as owners, it generally avoids investor groups or passive investors. Licensees, like franchisees, must adhere to the QSCV standards.

Franchisees are the key to McDonald's operation. Of its 31,667 stores (2006; includes 621 stores belonging to the Boston Market chain), McDonald's only owns and operates 8,785 (28\%); franchisees own and operate 18,687 (59\%), and affiliated companies own and operate 4,195 (13\%). Of total system-wide sales of US $\$ 57.5 \mathrm{bn}$, company-owned stores produced US\$16.bn (28\%), whereas franchisee and affiliated stores produced US $\$ 41.4 \mathrm{bn}$ (72\%). The company expects its franchises not only to meet the QSCV standards, but to have a commitment to McDonald's- - "to have ketchup in their veins".

To qualify for a franchise a prospective owner must make a substantial down payment that must come from non-borrowed personal resources, exclusive of the owner's home. This requirement is both a screening device and a bond. The down payment may signal past success, and because franchisees are betting their own money - if they fail, they lose their investment - the willingness to risk the payment signals self-confidence.

Furthermore, because franchisees would lose their down payment if they lose their license due to a failure to maintain the QSVC standards, they have an incentive to maintain those standards. Over time, as Kaufman and Lafontaine (1994) show, McDonald's "leaves money on the table" in that the franchise or license agreements permit the recipient to retain some of the economic rents from the venture, rents that grow as the venture grows. Revoking a license may be difficult and take time, but McDonald's has done so in Paris (1977-1982) and El Salvador (1996-8).

Lastly, McDonald's has a tradition of bottom-up innovation. As owners, the franchisees have an incentive to innovate to improve their profitability; menu innovations franchisees have introduced include the Big Mac, Fillet-o-Fish, and Egg McMuffin. Similarly, franchisees and affiliates have introduced operating innovations such as improved meat freezers (Sweden), pre-fabricated modular stores (The Netherlands), and mini, satellite stores (Singapore). This phenomenon demonstrates Knott's (2000) argument for the dynamic value of hierarchy. McDonald's management selects among the innovations and promotes the diffusion throughout the system of those that it thinks will benefit the 
company. McDonald's ability to appropriate the ideas may forestall some innovation, but provides it some recompense for letting franchisees and licensees retain a share of the economic rents accruing to their being part of McDonald's.

McDonald's has also spurred entrepreneurship indirectly by inspiring competitors. It has come to face local competitors in the hamburger market, and competition from entrepreneurs who have applied the fast food approach to indigenous or other cuisines. In several cases when the local entrepreneur created their chain before McDonald's arrived, the local firm has been able to retain the lead. This has occurred in developed and developing countries.

In Belgium, the market leader is the Quick hamburger chain, with 75 stores. Quick opened its first store in Belgium in 1971, after GIB, then Belgium's largest retailer, sent a management team to the U.S. to study and copy McDonald's. ${ }^{7}$ McDonald's didn't arrive in Belgium until 1978 and now has 57 stores there. (Quick also has nine stores in Algeria, Dubai, Morocco, and Réunion; McDonalds has 49 stores in Dubai, 18 in Morocco, and six in Réunion.)

In Peru McDonald's ten stores compete with Bembos' 30 stores, the differential in part a result of Bembos having opened in 1988, while McDonald's only entered in 1996. Furthermore, Bembos reports that it rejected McDonald's expression of interest in buying it. Wanting to expand internationally, Bembos considered entering Bolivia and Chile (Garcia et al., 2004), but in 2005 opened in Mexico. This initiative may have failed, but more recently Bembos has apparently opened stores in Mumbai and Panamá City, Panamá.

In the Philippines, Jollibee, which was established in 1973 as an ice-cream parlor and did not add fast-food until 1979, had only 11 stores by 1981 when McDonald's arrived. It now has 583 stores in the Philippines to McDonald's 250. Jollibee has expanded abroad; it operates a store each in Guam and Saipan, eleven in California, one in Nevada, and a handful spread over Hong Kong, Vietnam, and Brunei. ${ }^{8}$ Jollibee's core products are fried chicken, spaghetti, and hamburgers with a Pilipino flavor. McDonald's Philippines has had to introduce its McSpaghetti to match Jollibee's offerings.

As the Bembos and Jollibee cases show, often the local entrepreneurs have chosen not to tackle McDonald's head on, but rather to feature local tastes or other foods, copying the idea, but not the menu. In Canada, especially Quebec, McDonald's faces, among others, the Chez Ashton chain, which has built itself around poutine. Poutine, which originated in Quebec, is a locally popular combination of French fries, cheese curd, and gravy, augmented with such items

\footnotetext{
${ }^{7}$ In 2000 GIB sold Quick to the French retailer, Carrefour, the second largest retailer in the world after Walmart.

${ }^{8}$ However, it failed in Bahrain, Indonesia Kuwait, Papua New Guinea, Sarawak, Singapore, Saudi Arabia, and the UAE. Relative to McDonald's it faced difficulties in attracting good local partners, getting prime locations, and in appealing to non-Filipinos.
} 
as boiled peas, or pieces of sausage, hamburger, chicken, and the like. Chez Ashton began in 1969, but did not introduce poutine until 1972. McDonald's arrived in 1972 and now has over 280 stores versus Chez Ashton's 25; it too now offers poutine, in addition to its normal menu.

McDonald's largely dominates the French fast-food sector where it dwarfs Belgium's Quick chain and France's Elior group. Quick, which bought the O'Kitch chain in 1986 and Burger King's French stores in 1997, is the number two fast-food chain with 317 stores (McDonald's has 1085). ${ }^{9}$ Still, competition, and criticism, led McDonald's recently to overhaul its entire French operation by upgrading the décor, introducing new items, using more organic ingredients, providing nutritional labeling, and opening its stores to scrutiny. ${ }^{10}$

In Brazil, McDonald's competes with a number of local fast-food chains, including Habib's and Mister Sheik, two chains specializing in Middle Eastern cuisine. Habib's' Portugal-born founder saw an opportunity in offering Arabic fast-food (Plummer 2005). The menu includes hummus, esfihas, kibe, and the like, but also pizzas and burgers. Habib's has some 285 stores in Brazil, compared to McDonald's 542 stores, 549 kiosks, and 49 McCafés, but shelved its plan to open in Florida after the Islamist terrorist attack on the US on September 11, 2001. Instead Habib's opened six stores in Mexico.

McDonald's opened its first mainland Chinese store in Shenzhen in 1990 and has some 670 outlets in some 70 cities. Now dozens of local competitors have established operations that offer fare ranging from Chinese-style beef noodles to soy milk.

This far from exhaustive list simply illustrates the point that in many countries where McDonald's now operates, and even in some where it does not, local entrepreneurs have sought to apply the McDonald's model, with modifications. (McDonald's does not operate in Kyrgyzstan; however, there are a number of individual entrepreneurs and chains, including one calling itself Mac Burger, which offer a split bun filled with shavings from a rotating wheel of some sort of grilled meat, augmented with slaw, mayonnaise, cucumber, tomato, and mini French fries, all lathered with ketchup.) The key point is that McDonald's inspired imitators, some of whom are now challenging it in third markets, and even in the US. The diffusion of both the hamburger and the fast-food production process thus has provided opportunities for local entrepreneurs.

\footnotetext{
${ }^{9}$ The O'Kitch chain belonged to the McDonald's franchisee in Paris who lost his license in 1982 for failure to maintain the QSCV standards. After he lost the license he changed the name on his stores and continued to operate.

${ }^{10}$ The move appears to have been successful, resulting in rapid growth in sales. Denis Hennequin, the Frenchman who was CEO of McDonald's in France and introduced the changes, is now CEO of McDonald's Europe, overseeing some 41 countries. He has introduced the McPassport, which appeals to young employees' desire to travel because it allows them to transfer to any McDonald's store within the European Union.
} 
Hunter and Ryan (2005) report that in Poland, transition has brought with it a remarkable growth of small and medium businesses, including the development of about 100 international and domestically created franchise businesses that employ over half a million Poles. Among the foreign franchise chains they list some nine fast food chains, including McDonald's and its major competitors.

\subsection{Backward linkages}

McDonald's is not vertically integrated. Instead, it seeks out local suppliers, or works with independent suppliers with whom it has been able to establish an alliance. This strategy frees McDonald's to concentrate on retailing, reduces transportation costs and exchange rate risk, and builds local political support.

Ray Kroc realized that the chain's success lay in its process, and that he could eschew vertical integration; consequently, he sought out small, hungry companies as suppliers, doing business on a handshake. Today, many suppliers have an open-book relationship in which McDonald's sets their profits. Although McDonald's is often a monopsonist, with the supplier having no contract, McDonald's prizes relationships with the firms that can meet its demanding quality and service standards. It doesn't shop around for the lowest price and the supplier may equally end up as a monopolist vis-à-vis McDonald's.

For instance, when McDonald's entered Mexico in 1985, McDonald's buyer visited Bimbo Bakeries, a local company, but Bimbo's buns failed a taste test (Millman 2000). A shocked Bimbo's chairman decided to invest US\$30 million in a successful bit to bring his products up to McDonald's standards. Bimbo first became a preferred supplier for bread products for McDonald's in Mexico, and then its exclusive supplier. Since 1999, Bimbo has qualified to provide all the bread products for McDonald's in Peru and Venezuela, and in Colombia where it has a joint-venture with a local firm.

Another example comes from Bolivia. When McDonald's entered in 1997, it contracted with Frigosa for hamburger meat, La Francesa for buns, and Hipermaxi for iceberg lettuce, but required them to upgrade their technology and know-how (Anon. 1997).

In Russia, however, McDonald's had to set up its own supply operation. In 1986 McDonald's Canada and the City of Moscow established a joint-venture in which the City took a $51 \%$ share in return for providing the site; McDonald's Canada took a $49 \%$ share, but received complete management authority. ${ }^{11}$ Part of the five years of preparation that preceded the opening of the first store in 1990 involved McDonald's building its "McComplex" production center outside the

\footnotetext{
${ }^{11}$ McDonald's now wholly-owns its Russian operation.
} 
city. The production center still operates but McDonald's now also has local Russian suppliers.

In Brazil, McDonald's established Food City in 1999, which is a facility that unites several of its suppliers in one location. The suppliers are Braslo, which provides hamburgers and chicken, Interbakers, which provides bread products, and Martin-Brower, which manages the complex and provides the logistics to get the food to McDonald's stores.

\subsection{Promoting exports}

After McDonald's certifies products for use in its local stores, it works with the manufacturers to enable them to supply McDonald's stores in neighboring countries as well. Being an ally of McDonald's in several markets strengthens the alliance for both the local firm and McDonald's. Furthermore, by facilitating exports, McDonald's reduces host-government concerns about the Balance of Payments effects of its imports of those products it cannot source locally. Incidentally, the McComplex in Russia now exports to almost 20 other countries, including Germany and Austria.

There are many cases of McDonald's providing an export market to its suppliers. The Colombian firm that provides uniforms to McDonald's in Colombia also provides them in Chile, Peru, and Venezuela. The Colombian supplier of cups and lids also exports to other McDonald's elsewhere.

McDonald's largest international supplier of French fries is McCain Foods, a privately-owned firm based in New Brunswick, Canada. McCain is the world's largest maker of French fries and includes McDonald's competitors such as KFC among its customers. McCain has more than 55 plants (producing a variety of foods, not just potato-based ones) in 18 countries and sells to over 100 countries. The Moscow McComplex depended on McCain's extensive involvement in order to produce the requisite McDonald's fries. When McCain opened its first plant in Latin America in 1996, in Argentina, it did so to supply McDonald's in Argentina, Brazil, and Uruguay.

In 1971, McDonald's entered Australia and turned to FJ Walker Foods, a local company, for its beef. Today, FJ Walker and Australian Food Corporation export beef patties to Japan, Korea, Hong Kong, Indonesia, Kuwait, Morocco, and Saudi Arabia, and provide a McDonald's world reference beef patty; their patties provide the standard for measuring the quality of beef patties made in other McDonald's around the world.

In effect, McDonald's forces its suppliers to meet world standards; selling to McDonald's is the equivalent of exporting. As the examples show, having met world standards, McDonald's suppliers are able to export not only to McDonald's, but also in their own name to a variety of foreign markets. 


\subsection{Generating positive externalities}

A recent report on a series of McKinsey case studies that included the food retailing sector in Mexico and Brazil, suggests that FDI generates positive externalities (Farrell et al., 2004). In the sectors studied, FDI raised productivity and output levels, while it lowered prices and improved the quality and selection of products and services for consumers. Furthermore, the authors found that in every instance the foreign companies paid employees wages that were equal to or greater than those that domestic competitors paid.

Smarzynnska Javorcik et al., (2006) studied the effect of Wal-Mart on the Mexican soap, detergent and surfactants (SDS) industry. They found that Walmex (Walmart's Mexican operation), fundamentally changed the retail sector by forcing suppliers to cut their profit margins or innovate. Those unable to meet the standards lost market share and in some cases disappeared; at the same time the industry exhibited impressive efficiency gains.

But FDI can bring other, perhaps subtler externalities. McDonald's emphasis on cleanliness, including or especially in restrooms, has led its competitors to upgrade their facilities. Before the first McDonald's opened up in 1975, restrooms in Hong Kong's restaurants were notoriously dirty (Watson 1997). Over time, competitors felt compelled to meet McDonald's cleanliness standards. The same thing appears to be occurring in China (Watson 2000). In Korea, McDonald's introduced the practice of lining up in an orderly fashion to order food; traditional practice was simply to crowd the counter, with success in ordering accruing to the most aggressive (Watson 2000). In the Philippines, Jollibee mimics McDonald's clean and well-lighted look.

A third area where the presence of McDonald's may raise standards is in animal welfare. Grandin and Johnson (2005), in a fascinating and strange book (Grandin is autistic and has a $\mathrm{PhD}$ in Animal Science), explain the criteria and audit forms for humane slaughter and handling that Dr. Grandin developed for the American Meat Institute. In 1999, McDonald's hired Dr. Grandin to implement her audit criteria and train their auditors. McDonald's initially implemented the audits for its suppliers in the US and since then has extended them to its suppliers elsewhere. McDonald's reports that in 2004, its auditors completed nearly 540 audits to cover the majority of the facilities that provide it with its meat products in all the major geographic sectors in which it operates. Because Dr. Grandin's approach changes how the suppliers operate their plants, any improvements in the treatment of animals intended for McDonald's apply to all animals the plants process. At the same time, McDonald's recognizes that local business units may develop additional standards and compliance systems as appropriate to local legal, supply chain, and cultural conditions. For instance, depending on the country, or even the store, slaughtering may have to conform to religious requirements such 
as the halal and kashrut (kosher) rules. More generally, in 2005 the Royal Society for the Prevention of Cruelty to Animals in the UK praised McDonald's for its cattle handling standards and gave the company an award because it had shifted its egg suppliers to those that produced only free-range eggs.

\subsection{Limitations of the argument}

McDonald's only goes to countries where it is confident that it can maintain its QSCV standards. This eliminates many countries where it can neither find nor introduce the supplies it needs, or operate safely.

In 1999 Thomas Friedman wrote, "No two countries that have McDonald's have ever fought a war since each got McDonald's," which was really an argument about the salutary effects of trade and integration. However, what the observation suggests is that McDonald's tends to enter countries that are integrated into the world economy and that can provide some level of political stability. Political stability does not always last-McDonald's had to withdraw from Nicaragua for some years - and Friedman's observation is not infallible. ${ }^{12}$ Still, in general, the observation holds.

In Nicaragua during the Sandinista regime (1979-1990) and civil war (1981-1989), the licensee was unable to maintain McDonald's standards so in 1980 asked the company to suspend his license. He continued to operate under the name "Donald's" until McDonald's return in 1998. (Offered the license, he transferred it to his daughter, who had gone to work for McDonald's in Spain.)

Two correlates of McDonald's presence are per capita GDP and the rule of law. We use as a proxy for the rule of law Transparency International's (TI) Corruption Perception Index (CPI); of the 132 countries that TI rated in 2003, the least corrupt country was Finland, with a score of 9.7 (10 is maximum); the most corrupt was Bangladesh, with a score of 1.3. (The US score was 7.5.)

If we regress a $(1,0)$ dummy variable for the presence of McDonald's $(1=$ present) on TI's index, the total urban population, per capita GDP, and urban GDP (urban population times per capita GDP), we get the following results (with t-statistics in parentheses):

$$
\begin{aligned}
\text { Prob }(\text { Presence }=1)= & 0.23+0.085 \text { TICPI }+0.0019 \text { Urban population } \\
& (2.06)(2.47) \quad(2.53) \\
& +0.0033 \text { per capita GDP }-0.0000 \text { Urban GDP } \\
& (0.50)
\end{aligned}
$$

\footnotetext{
${ }^{12}$ The exceptions include the 1989 United States invasion of Panamá, the 1999 NATO (US) bombing of Serbia, and arguably, the 2006 Lebanon War.
} 
The standardized coefficients are 0.42 and 0.09 for the TICPI and per capita GDP; clearly, the rule of law provides a much better explanation for McDonald's presence than income levels, though of course the two are correlated (0.88). With a standardized coefficient of 0.23 , the size of the urban population is also an important variable; per capita GDP and total urban GDP (whose standardized coefficient is -0.07 ), are not.

In terms of predictions, the model generates 11 false positives, many of which are in Africa, and a number of which one can readily explain by idiosyncratic factors, such as, for example, the absence of McDonald's from Iran, Gaza and the West Bank, and Syria. One false positive is Trinidad and Tobago, which McDonald's entered in 1994 but left in 2003. The model also generates 11 false negatives; several of these are Central American states such as Guatemala, Honduras, and Nicaragua, and Transition Economies such as Azerbaijan, Georgia, and the Ukraine. Many of the false negatives may simply represent the availability of an entrepreneur willing to pull McDonald's in before it seeks to push itself forward. The examples of McDonald's success in unlikely venues around the world, particularly France and Japan, and its few failures - it is in about 120 countries, has withdrawn from six, half of which it has returned tosuggests that some of these entrepreneurs may well be prescient. ${ }^{13}$

\subsection{Conclusion}

McDonald's does not lack criticism. However, examination of its international operations raises the possibility that perhaps it deserves some plaudits too, suggesting the appropriateness of a more nuanced assessment. The anecdotal evidence suggests that various aspects of its presence in host countries deserve further investigation. It would be worthwhile for researchers to establish the scale of the benefits that McDonald's and its fast food brethren bring in the areas of providing management training, encouraging entrepreneurship, developing local suppliers, promoting exports, and improving productivity, standards of service, and animal welfare.

However, the little statistical exercise in the previous sections suggests two caveats. First, cross-national studies are not likely to be useful in testing the argument and establishing the scale of the benefits; intra-country case studies and surveys are more likely to prove fruitful. Secondly, the results suggest the existence of a virtuous circle: countries that succeed in institutionalizing some rule of law and that are open to the world will be recipients of McDonald's presence and the attendant benefits. Countries that cannot meet these criteria will be left behind.

\footnotetext{
${ }^{13}$ The three from which it withdrew and has not yet returned are arguably Bermuda (1997-2002), and Bolivia (1997-2002) and Trinidad and Tobago (1994-2003).
} 
Tschoegl: McDonald's -- Engine of Development

\section{Bibliography}

Beaulier, S. and B. Caplan. 2007. Behavioral Economics and Perverse Effects of the Welfare State. Kyklos 60 (4), 485-507.

Beveridge, W.I.B. 1961. The Art of Scientific Investigation. New York: Vintage.

Anonymous. 1997. McDonalds Opens in Bolivia. Bolivian Times V (43; October).

Brailsford, I. 2003. 'US Image but NZ Venture': Americana and Fast-Food Advertising in New Zealand, 1971-1990. Australasian Journal of American Studies 22 (2), 10-24.

Brandt, E. 1991. Global HR. Personnel Journal 70 (3), 38-44.

Capelli, P. and M. Hamori. 2007. Are Franchisees Bad Employers? Industrial and Labor Relations Review (Forthcoming).

Den Beste, S. 2002. http://denbeste.nu/cd log entries/2002/04/BurgessandWWIIIII.shtml Accessed 23 Dec 2005.

Farrell, D., J.K. Remes, and H. Schulz. 2004. The truth about foreign direct investment in emerging markets. McKinsey Quarterly No. 1, 25-35.

Faulk, S. and J-C. Usunier. 2004. McDonald's: A global cultural icon? European Case Clearing House 205-003-1.

Friedman, T.L. 1999. The Lexus and the Olive Tree. New York: Farrar.

Garcia, L. M., R. Revilla, and C.G. Sequeira. 2004. Bembos Burger Grill. Journal of International Business Education 1 (1), 111-144.

Grandin, T. and C. Johnson. 2005. Animals in Translation. New York: Scribner.

Greenberg, J., and M. Naim. 2001. The FP Interview: McAtlas Shrugged. Foreign Policy, no. 124 (May-Jun), 26-37.

Hunter, R.J., and L.V. Ryan. 2001. A Transitional Analysis of the Polish Economy: After Fifteen Years, Still a "Work in Progress". Global Economy Journal 5 (2), article 6.

Kaufman, P.J., and F. Lafontaine. 1994. Costs of Control: The Source of Economic Rents for McDonald's Franchisees. Journal of Law and Economics 37 (2), 417-453.

Kornai, J. 1976. Pressure and Suction on the Market, in: Economic Analysis of the Soviet Type System. Ed.: J. Thornton. Cambridge: Cambridge University Press, 191-215. 
Kokko, A.R. 1996. Productivity Spillovers from Competition between Local Firms and Foreign Affiliates. Journal of International Development 8 (4), 517-530.

Kokko, A., R. Tansini, and M.C. Zejan. 1996. Local Technology Capabilities and Productivity Spillovers from FDI in the Uruguayan Manufacturing Sector. Journal of Development Studies 32 (4), 602-611.

Kostova, T., and S. Zaheer. 1999. Organizational Legitimacy Under conditions of Complexity: The Case of the Multinational Enterprise. Academy of Management Review 24 (1), 64-81.

Knott, A. M. 2002. The Dynamic Value of Hierarchy. Management Science 47 (4), 430-448.

Love, J.F. 1986. McDonald's: Behind the Arches. New York: Bantam.

Meyer, K.E. and E. Sinani. 2006. Spillovers from Foreign Direct Investment: A Meta-Analysis. University of Reading, unpublished paper presented at the Academy of International Business Conference, Beijing.

Millman, J. 2000. The World's New Tiger on the Export Scene Isn't Asian: It's Mexico. Wall Street Journal (May 5).

Nachum, L., G.G. Jones and J.H. Dunning. 2001. The international competitiveness of the UK and its multinational corporations. Structural Change and Economic Dynamics 12 (3), 277-294.

Plummer, R. 2005. Giving Brazil a taste of Arabia. BBC News. http://news.bbc.co.uk/go/pr/fr/-/2/hi/business/4468070.stm

Schlosser, E. 2002. Fast Food Nation. New York: HarperCollins.

Server, A.E. 1994. McDonald's Conquers the World. Fortune (October 17), 103116.

Smarzynska Javorcik, B., W. Keller, and J. Tybout. 2006. Openness and Industrial Responses in a Wal-Mart World: A Case Study of Mexican Soaps, Detergents and Surfactant Producers. NBER WP 12457.

Sowell, T. 1987. Compassion Versus Guilt, and Other Essays. New York: W. Morrow.

Vernon, R. 1966. International Investment and International Trade in the Product Cycle. Quarterly Journal of Economics 80, 190-207.

Watson, J.L. ed. 1997. Golden Arches East: McDonald's in East Asia. Stanford: Stanford University.

Watson, J.L. 2000. China's Big Mac Attack. Foreign Affairs 79 (3), 120-134.

DOI: $10.2202 / 1524-5861.1327$ 